\title{
Assessing climate change impacts on crops by adopting a set of crop performance indicators
}

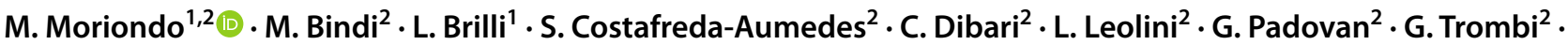 \\ A. Karali ${ }^{3} \cdot$ K. V. Varotsos ${ }^{3} \cdot$ G. Lemesios ${ }^{3} \cdot$ C. Giannakopoulos ${ }^{3} \cdot$ C. Papadaskalopoulou ${ }^{4} \cdot$ P. Merante ${ }^{5}$
}

Received: 30 June 2020 / Accepted: 28 January 2021 / Published online: 2 April 2021

(c) The Author(s) 2021

\begin{abstract}
The impact of climate change on the agricultural systems of three major islands in the Mediterranean basin, namely Sicily, Crete and Cyprus, was evaluated using a suite of specifically calibrated crop models and the outputs of a regional circulation model for Representative Concentration Pathway (RCP) 4.5 and 8.5 downscaled to $12 \mathrm{~km}$ of resolution and tested for its effectiveness in reproducing the local meteorological data. The most important annual (wheat, barley, tomato and potato) and perennial (grapevine and olive tree) crops were selected to represent the agricultural systems of the islands. The same modelling framework was used to test the effectiveness of autonomous adaptation options, such as shifting sowing date and the use of varieties with different growing season length. The results highlighted that, on average, warmer temperatures advanced both anthesis and maturity of the selected crops, but at different magnitudes depending on the crop and the island. Winter crops (barley, wheat and potato) experienced the lowest impact in terms of yield loss with respect to the baseline, with even some positive effects, especially in Sicily where both wheat and barley showed a general increase of $9 \%$ as compared to the baseline, while potato increased up to $+17 \%$. Amongst perennial crops, olive tree showed low variation under RCP 4.5, but on average increased by $7 \%$ under RCP 8.5 on the three islands. Climate change had a detrimental effect specifically on tomato ( $-2 \%$ on average in RCP 8.5 and 4.5 on the three islands) and grapevine (-7\%). The use of different sowing dates, or different varieties, revealed that for winter crops early autumn sowing is still the best option for producing wheat and barley in future periods on the three islands under both future scenarios. For tomato and potato, advancing sowing date to early winter is a winning strategy that may even increase final yield (+ $9 \%$ for tomato and $+17 \%$ for potato, on average). For grapevine, the use of late varieties, while suffering the most from increasing temperatures and reduced rainfall (- $15 \%$, on average), is still a valuable option to keep high yield levels with respect to earlier varieties, which even if showing some increases with respect to the baseline have a generally much lower production level. The same may be applied to olive tree although the production differences between late and early varieties are less evident and climate change exerts a favourable influence ( +4 and $+3 \%$ for early and late varieties, respectively).
\end{abstract}

Keywords Crop modelling $\cdot$ Extreme events $\cdot$ Agriculture $\cdot$ Adaptation $\cdot$ Climate change

Communicated by Elena Xoplaki, Chief Editor.

M. Moriondo

marco.moriondo@cnr.it

1 CNR-IBE, via Madonna del Piano 10, Sesto Fiorentino, 50019 Florence, Italy

2 Department of Agriculture, Food, Environment, and Forestry (DAGRI), University of Florence, P.le delle Cascine 18, 50144 Florence, Italy

3 Institute for Environmental Research and Sustainable Development, National Observatory of Athens, Lofos Koufou, P. Pendeli, 15236 Athens, Greece
4 School of Chemical Engineering, National Technical University of Athens, 9 Iroon Polytechniou Str., Zographou Campus, 15773 Athens, Greece

5 Tropical Plant Production and Agricultural Systems Modelling (TROPAGS), Georg-August-University Göttingen, Grisebachstraße 6, 37077 Göttingen, Germany 


\section{Introduction}

Agriculture is inherently dependent on weather conditions, and even a small variation from usual temperatures or changes in rainfall frequency can expose this sector to yield losses. With the ongoing climate change, these risks are expected to further increase, leading to detrimental effects on crop development and productivity and consequent economic losses for communities (Howden et al. 2007).

The Mediterranean region, where an upward trend in temperatures associated with a rain deficit has already been highlighted (Giorgi and Lionello 2008; Kovats et al. 2014; Vicente-Serrano et al. 2014; Lionello and Scarascia 2018), is one of the most sensitive areas to climate change in the world, and further alterations to mean climate conditions and variability, as expected in the future, may lead to highly detrimental conditions for the agricultural sector of this region (Moriondo et al. 2011; Cramer et al. 2018; Webber et al. 2018). Several aspects of climate change contribute to crop vulnerability. Crop phenology is largely dependent on temperature, and a warmer climate would shorten the growing cycle and, consequently, the time for biomass accumulation, thus resulting in smaller plants and lower yields (Asseng et al. 2011; Moriondo et al. 2011). The increase in extreme events, such as heat stress and drought, are additional factors that reduce crop yield, especially when these events occur during the most sensitive stages of plant growth (Challinor et al. 2005; Moriondo et al. 2010, 2011; Webber et al. 2018). Although future climate projections are affected by uncertainties, most studies conducted on the Mediterranean basin indicate a worsening climate pattern, consisting of a further temperature increase and a decrease in the total amount of precipitation associated with an increase in intensity (Giorgi and Lionello 2008), which, in turn, may lead to a yield reduction in the main commercial crops and related detrimental effects on the economic viability of the agricultural sector (Brilli et al. 2014; Papadaskalopoulou et al. 2020).

Specific tools are required to consider this complex interaction between climate change and variability and crop growth, and crop modelling is a particularly suitable approach since it can combine knowledge of plant physiological processes in response to abiotic stresses with future climate conditions as simulated by regional circulation models (RCMs) (Challinor et al. 2014; Asseng et al. 2015; Ewert et al. 2015). Although this approach has been applied, the impact of climate change on the Mediterranean basin has to date been limited to general conclusions that range from the national level (e.g. Moriondo et al. 2010; Georgopoulou et al. 2017) to a very local scale (e.g. Moriondo et al. 2015; Cammarano et al. 2019), and generally centred on a single crop. Conversely, the needs for adaptation of agricultural systems require an extensive local analysis of the impact of climate change on the yield of those crops contributing most to the economy. Papadaskalopoulou et al. (2020) pointed out that while $20 \mathrm{EU}$ countries have conducted Climate Change Impact and Vulnerability (CCIV) assessments for their agricultural sectors (European Environment Agency 2018), these are based on the literature or expert advice. In addition, national CCIV assessments based on the results of research projects have been produced, but these are not useful for assessing local climate change impacts and adaptation plans.

In this paper, we focus on assessing the impacts of future climate on the agricultural sector of three Mediterranean islands considered to be particularly vulnerable to climate change, namely Crete, Cyprus and Sicily, using of a suite of crop models to simulate the impacts on the major cultivated crops (wheat, barley, potato, tomato, grapevine and olive tree) driven by RCMs downscaled at high spatial resolution. These study areas were chosen taking into account the detrimental conditions that their agricultural sectors are currently experiencing, with the aim to provide a tool for climate change adaptation. For such a purpose, shifting sowing dates or using varieties with different growing season length were tested to identify feasible adaptation options in the short term. This assessment may be considered the first step in a comprehensive evaluation of climate change impact that encompasses the evaluation of crop performances and their consequences on the local economic fabric (Papadaskalopoulou et al. 2020).

\section{Materials and methods}

\section{Study areas and crop selection}

The three study areas (Crete, Cyprus and Sicily) are located in the center of the Mediterranean basin (Fig. 1).

Crete The utilised agricultural area (UUA) on Crete consists of arable land, permanent crops, pastures (i.e. transitional forest/shrub land, pastures), combined shrub land/herbaceous plants and heterogeneous agricultural areas, occupying approximately $70 \%$ of the total island surface (Hellenic Statistical Authority 2000/2010; https://www.statistics.gr/ en/greece-in-figures). The main cultivated crops are those typical of the Mediterranean basin, such as olive and fruit trees and grape, while annual crops (e.g. wheat, potato and tomato) cover a small percentage of the UAA.

Cyprus The central plain of Cyprus is characterised by wheat and barley rain-fed cultivation. Potatoes, vegetables, legumes and fodder crops are grown throughout the island. 


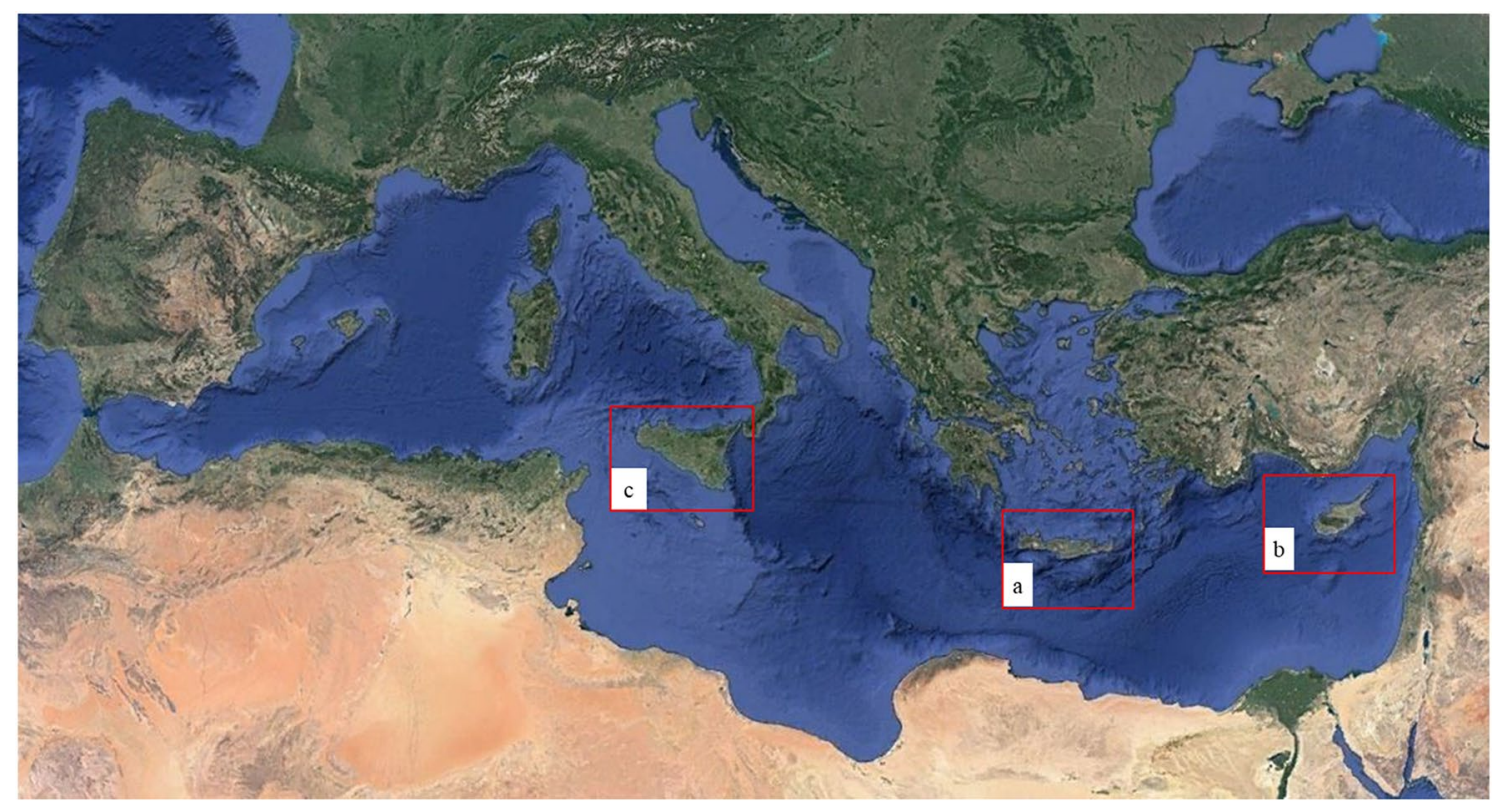

Fig. 1 Location of the three study areas in the Mediterranean basin: Crete (a), Cyprus (b), Sicily (c)

Grapes are mainly found in the hilly areas of Paphos and Limassol, while table grapes are grown mainly in the southwestern areas near the sea.

Sicily Arable land, vineyards, permanent crops, permanent grassland, pastures and meadows cover approximately $89 \%$ of the total UAA on Sicily. The remaining UAA is land with short rotation coppices, wooded areas and other land. The main cultivated crops are wheat, citrons, oranges, lemons, olives, artichokes, almonds, grapes and pistachios, while potatoes and tomatoes cover a small area.

\section{Selection of regional climate models}

A set of four RCM simulations performed within the framework of EURO-CORDEX (Coordinated Regional Climate Downscaling Experiment) were evaluated against the gridded observational dataset of E-OBS (v13) (Haylock et al. 2008) for the period 1971-2005. The four regional climate model experiments with a horizontal resolution of about $12 \mathrm{~km}\left(0.11^{\circ}\right)$ were basically the RCA4 regional climate model of the Swedish Meteorological and Hydrological Institute (SMHI) (Strandberg et al. 2014, and references therein) driven by three different global climate models, namely (1) the CNRM-CM5 (Voldoire et al. 2013), hereafter referred to as CNRM-RCA4; (2) the Hadley Centre Global Environmental Model version 2 Earth System (HadGEMES; Collins et al. 2011; Martin et al. 2011) of the Met Office Hadley Centre (MOHC), hereafter referred to as MOHCRCA4; and (3) the Max Planck Institute for Meteorology model MPI-ESM-LR (Popke et al. 2013), hereafter referred to as MPI-RCA4; and (4) the ALADIN RCM version 5.2 of the Météo France Institute (CNRM) (Herrmann et al. 2011) driven by the CNRM-CM5 (Voldoire et al. 2013), hereafter referred to as CNRM-ALADIN. The three first simulations are basically the RCA4 regional climate model with boundary conditions from three different global models.

Taylor plots are used to compare seasonal climatology between the E-OBS and the models (Taylor 2001). These plots synthesise three spatial measures-standard deviation $(S)$, centred root-mean-square difference $(R)$ and correlation $(C)$-in a single bi-dimensional plot. The Taylor plots for the winter (December, January and February [DJF]) and summer (June, July and August [JJA]) daily maximum and minimum are shown in Fig. 2.

For winter temperatures, spatial correlations are mostly lower than 0.7 while the results are better for the summer season. In DJF the correlations are typically in the range 0.4-0.6, but higher values of up to 0.9 are obtained for the daily maximum temperature (TX) in Sicily from all models. Summer correlations are typically about 0.9 , reaching higher than 0.95 in some cases. Values of less than 0.9 are observed only in Sicily for daily minimum temperatures (TN). Regarding the standard deviation, most of the models tend to overestimate the magnitude of temperature variability in both winter and summer, especially in Crete and Cyprus, in some cases reaching up to 1.5 , which indicates that the variability is overestimated by $50 \%$. In Sicily the metric's values in most of the cases are $<1$, indicating an underestimation of the variability in both winter and summer. It should be highlighted that in most cases the lowest values, for both overestimation and underestimation of 

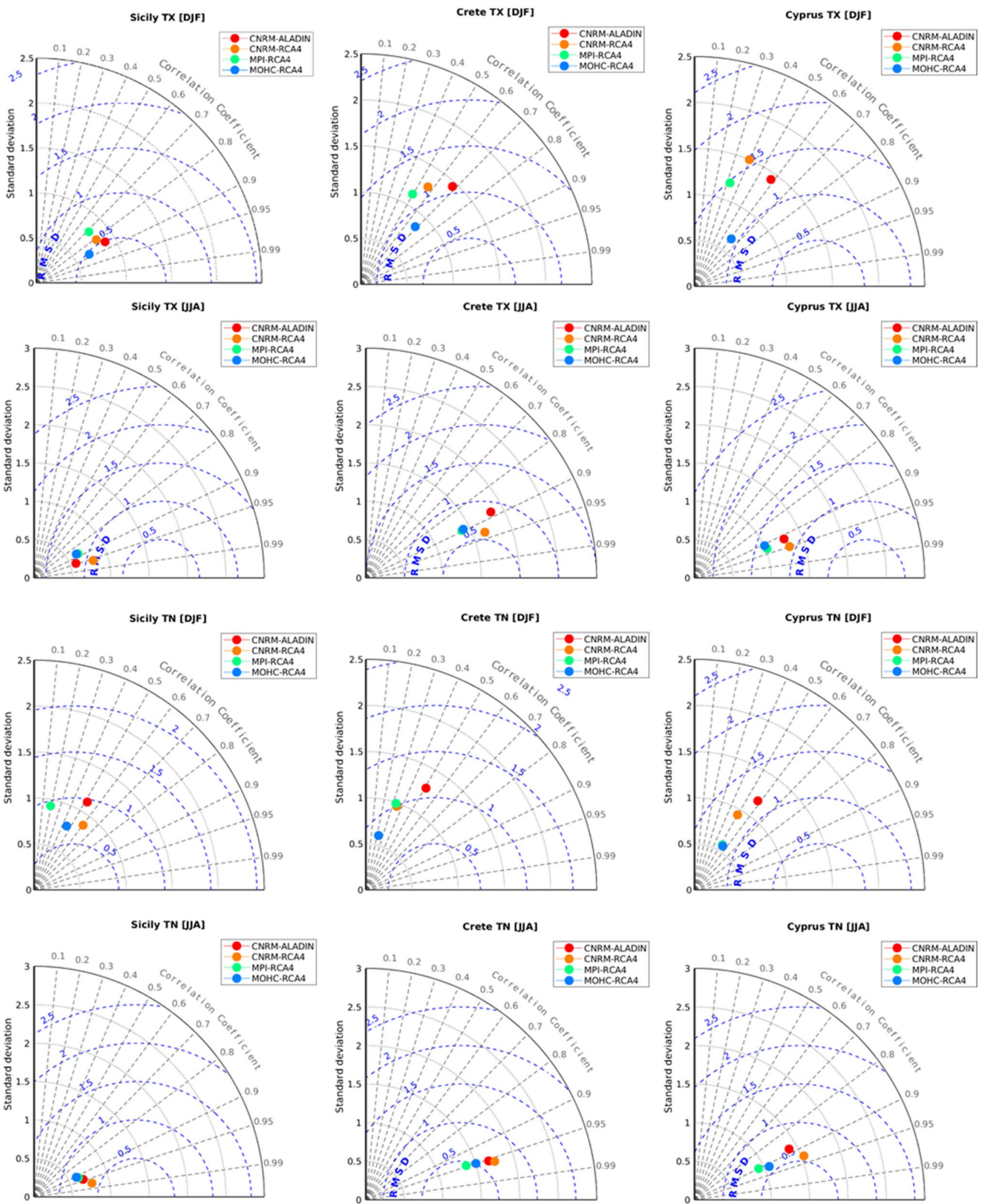

Fig. 2 Taylor diagrams exploring the model performance against the gridded observational dataset of E-OBS for the daily maximum (TX) and daily minimum $(T N)$ temperatures in winter ( $D J F$, December, January, February) and summer (JJA, June, July, August) for the three islands 
the variability and for both seasons, are calculated for the SMHI model driven by the MPI and MOHC climate global models. In addition, these two models seem to exhibit the lowest root-mean-square deviation (RMSE) errors. However, between these two models the one that seems to better capture the temporal pattern of the observations in terms of correlation coefficient and RMS error, both higher and lower values respectively, is the MOHC-SMHI model that was selected to perform crop growth simulations.

\section{Description of the crop simulation models}

In this study were used three different simulation models: (1) CropSyst (for wheat, barley, tomato and potato); (2) the Olive model (for olive trees); (3) UNIFI.GrapeML (for grapevine).

CropSyst (CS) (Stöckle et al. 2003) simulates the main crop phenological stages (emergence, anthesis, grain filling and maturation), potential biomass accumulation as dependent on radiation and water use efficiency (RUE $\left[\mathrm{g} \mathrm{MJ}^{-1}\right]$ and WUE [KPa $\mathrm{kg} \mathrm{m}^{-3}$, respectively) and plant transpiration, which is reduced to actual biomass if water or nitrogen conditions are limiting. Final yield is calculated considering the impact of heat stress at anthesis as a reducing factor (Moriondo et al. 2011, 2015). The model requires meteorological data on a daily time step (maximum and minimum air temperature, rainfall, global solar radiation) and soil available water-holding capacity. The model accounts for the effect of higher $\mathrm{CO}_{2}$ concentration by increasing WUE and RUE.

The Olive model (OLIVEmodel.CNR; Moriondo et al. 2019) simulates the growth and development of the olive agroecosystem on a daily time step considering the competition for water between weeds and olive trees. The key process of the model is the simulation of daily potential biomass increase for both olive trees and weeds as dependent on the relevant intercepted radiation and WUE/RUE. The potential biomass accumulation is then corrected by considering the effect of water stress. Both heat stress and drought at anthesis are considered as additional factors that reduce final yield. The model requires meteorological data on a daily time step (maximum and minimum air temperature, rainfall, global solar radiation), soil available water content and management practices (plant density, crown dimensions and initial leaf area index). The model accounts for the effect of higher $\mathrm{CO}_{2}$ concentration by increasing WUE and RUE.

UNIFI.GrapeML (Leolini et al. 2018) is a BioMA (http:// www.biomamodelling.org/) software model library jointly developed by the University of Florence (UniFI) and the Florence Agriculture and Environment Research Centre (CREA-AA) and used for simulating vine development and growth under different pedo-climatic conditions. The model architecture takes into account eight main plant processes: (1) phenological development, which estimates bud-break, flowering, veraison and maturity occurrence; (2) leaf area growth and light interception; (3) biomass accumulation as dependent on intercepted radiation and WUE/RUE; (4) biomass partitioning among single plant organs. The model requires meteorological data on a daily time step (maximum and minimum air temperature, rainfall, global solar radiation), soil available water content and management practices (plant density, number of shoots). The model accounts for the effect of higher $\mathrm{CO}_{2}$ concentration by increasing WUE and RUE.

\section{Calibration and validation of crop models}

\section{CropSyst}

CropSyst was specifically calibrated to reproduce crop yield and phenology of barley and wheat, while for potato and tomato the relevant parameters that had previously been calibrated for specific varieties were applied.

For wheat, phenological data (sowing time, anthesis and harvest) and final yield data were obtained from varietal trials conducted in Caltagirone (Sicily, Italy) and Oristano (Sardinia, Italy) for the cv. Bronte. The dataset spanned 1996-2005 in Caltagirone and 1997-2000 in Oristano. For barley, the same data were obtained from experimental trials conducted in Foggia (Apulia, Italy) for cv Mattina between 1998 and 2008. For potato, data were calibrated specifically for potato cv. Jendevad, while for tomato the default calibration provided in Cropsyst was used. A preliminary calibration of phenology was performed by modifying degree-day accumulation (DDA) from sowing to anthesis and to harvest time for wheat and barley varieties. Finally, both RUE and WUE were iteratively tested on values ranging from 2 to $6 \mathrm{~g} \mathrm{MJ}^{-1}$ and from 3 to $10 \mathrm{kPa} \mathrm{kg} \mathrm{m}^{-3}$, respectively, and the RUE/WUE pair providing the best performances in simulating final yield was selected. For wheat, data from Caltagirone and Oristano were pooled together.

\section{OLIVEmodel.CNR}

The model was calibrated and validated using experimental data from different sites located in the Tuscany region having heterogeneous climatic features as well as heterogeneous soil types and management practices. In brief, the model reproduces with accuracy soil water balance, total biomass accumulation and yield of olive trees as well as the competition for water with grass cover. Specifically, water balance was tested in a 25 -year-old orchard located at Istituto Tecnico Agrario Statale (ITAS) farm near Florence $\left(10.35^{\circ} \mathrm{E} 43.5^{\circ} \mathrm{N}\right)$ in 2017 ; net primary production (NPP) of the entire agro-ecosystem was tested against eddy covariance data (2010-2012) in a rain-fed olive orchard located in the "S. Paolina" 
experimental farm of the National Research Council at Follonica $\left(42.55^{\circ} \mathrm{N}, 10.45^{\circ} \mathrm{E}\right)$; total biomass accumulation and yield was tested in an experimental farm of the University of Pisa (2008-2010) under three different irrigation levels. For additional information, the reader is referred to Moriondo et al. (2019).

\section{GrapeModel}

UNIFI.GrapeML was calibrated for two grape cultivars, Chardonnay and Sangiovese. For cv. Chardonnay, the model was calibrated with observed data of phenology, soil water and grape yield retrieved in a vineyard located in Spain $\left(41.53^{\circ} \mathrm{N}, 1.7^{\circ} \mathrm{E} ; 340 \mathrm{~m}\right.$ a.s.1.). Climate, soil and management practices were monitored during the period 1998-2012. For cv. Sangiovese, phenology and grape quality data from Susegana, Treviso, Italy $\left(45^{\circ} 51^{\prime \prime} \mathrm{N}\right.$, $12^{\circ} 15^{\prime \prime} \mathrm{E} ; 83 \mathrm{~m}$ a.s.1) and Montalcino, Siena, Italy $\left(43^{\circ} 03^{\prime} \mathrm{N}, 11^{\circ} 29^{\prime} \mathrm{E} ; 326 \mathrm{~m}\right.$ a.s.l., Siena, Italy) were used for model calibration. More specifically, the phenological pattern was calibrated considering bud-break, flowering, veraison and maturity over the period 1964-2005, whilst grape quality was calibrated using data collected only at Montalcino during the period 1998-2015. For a more detailed description of the model and calibration strategy, the reader is referred to Leolini et al. $(2018,2019)$.

\section{Application of crop models}

The calibrated models were applied in the present period $1971-2000\left(\left[\mathrm{CO}_{2}\right]=360 \mathrm{ppm}\right)$ and in a future time slice 2031-2060 under Representative Concentration Pathway (RCP) $4.5\left(\left[\mathrm{CO}_{2}\right]=485 \mathrm{ppm}\right)$ and $8.5\left(\left[\mathrm{CO}_{2}\right]=540 \mathrm{ppm}\right)$ scenarios using the outputs of MOHC RCM, as described in the section Regional climate models selection. Soil texture and depth at the required spatial resolution were extracted for the three islands from the Harmonized World Soil Database maintained by the Food and Agriculture Organisation (FAO) of the United Nations.

Crop performances were tested, both in present and future scenarios, by using different sowing times (for sown crops) and different growing season lengths (for perennial crops). For barley, wheat, tomato and potato we considered shifting sowing times progressively from early to late in the relevant growing season (Table 1).

Varieties of grapevine and olive tree having a longer/ shorter growing cycle length were simulated by decreasing/ increasing the original number of days after anthesis (DDA) and days to maturity (Table 1).

\section{Selection and analyses of crop performance indicators}

Six performance indicators, provided by crop growth model simulations, were selected to summarise the impact of climate change on the selected crops: i) flowering and ii) maturity dates for crop phenology; iii) actual evapotranspiration

Table 1 Sowing dates tested for annual (barley, wheat, potato and tomato) and perennial (grape and olive trees) crops in the present period (1971-2000) and future period (2031-2060) under the RCP 4.5 and 8.5 scenarios

\begin{tabular}{|c|c|c|c|c|c|}
\hline Crop type & Sowing season/precocity & Sowing date & Budbreak (DOY) & Flowering (DOY) & Harvest (DOY) \\
\hline \multirow[t]{4}{*}{ Barley-Wheat } & Early autumn & 10 November & - & - & - \\
\hline & Late autumn & 30 November & - & - & - \\
\hline & Winter & 31 January & - & - & - \\
\hline & Spring & 15 February & - & - & - \\
\hline \multirow[t]{4}{*}{ Tomato } & Early winter & 30 January & - & - & - \\
\hline & Late winter & 28 February & - & - & - \\
\hline & Early spring & 30 March & - & - & - \\
\hline & Late spring & 31 April & - & - & - \\
\hline \multirow[t]{3}{*}{ Potato } & Late autumn & 20 October & - & - & - \\
\hline & Early winter & 15 November & - & - & - \\
\hline & Late winter & 25 December & - & - & - \\
\hline \multirow[t]{3}{*}{ Grapevine } & Early & - & $80-90$ & - & $235-240$ \\
\hline & Medium & - & $100-110$ & - & $260-270$ \\
\hline & Late & - & $110-130$ & - & $265-275$ \\
\hline \multirow[t]{2}{*}{ Olive tree } & Early & - & - & $145-155$ & $240-270$ \\
\hline & Late & - & - & $160-170$ & $300-330$ \\
\hline
\end{tabular}

DOY Days of year 
(AET, cumulated over the growing season); iv) potential evapotranspiration (PET, cumulated over the growing season) and v) the relevant ratio AET/PET; vi) the final yield. The phenological dates are indicators of growing cycle duration and the relevant changes that may occur under future climate conditions. The ratio between AET and PET is an indicator of water shortage during the season, where values lower than 1 (optimal growing conditions) indicate that soil water content is not able to meet crop water demand for optimal growth. Finally, crop yield can be considered the most effective indicator summarising the effect of climate change on of crop growing cycle length as well as water limiting factor to growth.
For each crop, the best management strategy for improving final yield, in terms of sowing date or duration of growing cycle, was evaluated prior to the study for both the baseline and future time slice (Table 1). The effect of climate change was then evaluated by comparing the relevant indicators for each sowing times/variety with respect to the baseline. Finally, with the aim to identify the sowing time or variety that would guarantee in any case the best yield in a changing climate, the highest yield in the present period was used as a baseline to evaluate the performances of crops under future scenarios to select the best solutions for adaptation.

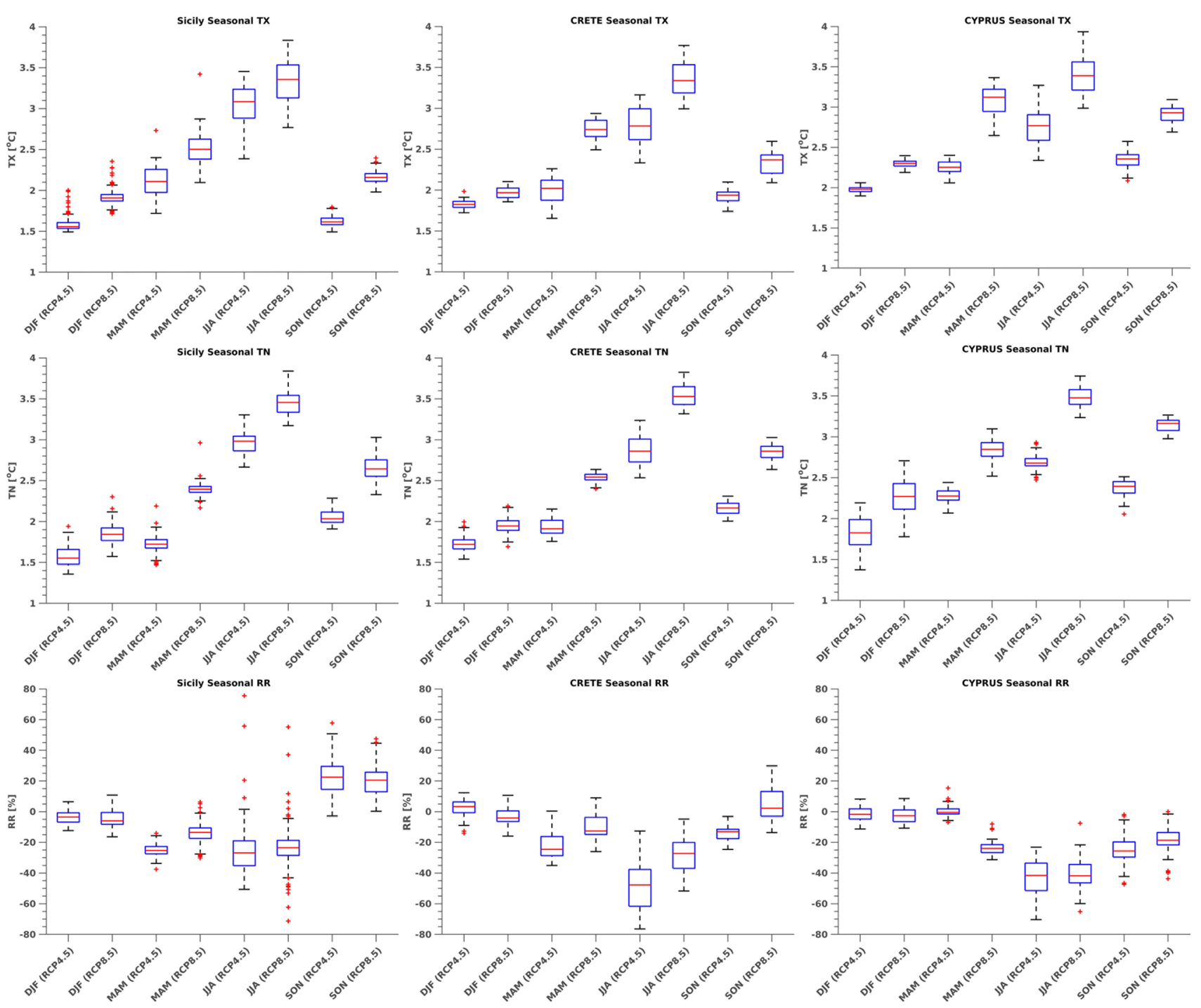

Fig. 3 Boxplots representing changes in temperature and cumulative rainfall for the period 2031-2060 with respect to the baseline 19702010. Data are reported for RCP 4.5 and 8.5. DJF Winter (December,
January, February), MAM= Spring (March, April, May), $J J A=$ Summer (June, July, August), SON Fall (September, October, November) 


\section{Results}

\section{Analysis of climate data}

The analysis of changes in temperature and cumulative rainfall for the period 2031-2060 with respect to the baseline present-day 1970-2010 scenario as simulated by MOHC suggested a common seasonal trend on the three islands (Fig. 3). The minimum and maximum temperatures progressively increased from winter (DJF) to summer (JJA), while they decreased in autumn (SON), with a different magnitude for the RCP 4.5 (lower) and RCP 8.5 (higher) scenarios. The highest increases were observed for RCP 8.5 in JJA, where both minimum and maximum temperatures increased by about $3.5^{\circ} \mathrm{C}$ on the three islands. In the same season, minimum and maximum temperature in RCP 4.5 were, on average, $3{ }^{\circ} \mathrm{C}$ higher with respect to the baseline. In DJF, the increase in temperatures, both minimum and maximum, on the islands was limited to between $1.5^{\circ} \mathrm{C}$ and $2{ }^{\circ} \mathrm{C}$ for RCP 4.5 , and between $1.5^{\circ} \mathrm{C}$ and $2.5^{\circ} \mathrm{C}$ for RCP 8.5. In $\mathrm{SON}$, the increase in both minimum and maximum temperatures was limited, depending on the island and scenario, ranging from $1{ }^{\circ} \mathrm{C}$ to $3{ }^{\circ} \mathrm{C}$. Cumulated rainfall progressively decreased from DJF when, on average, no relative changes were detected between the future period and the baseline for both scenarios, to JJA, where a decrease of $-50 \%$ (Crete, RCP 4.5) to - 30\% (Sicily, RCP 4.5) was observed. In general, a few differences were observed between RCP 4.5 and 8.5 in this season. In SON, the decrease in rainfall rate was less evident with respect to JJA in Cyprus (from - $40 \%$ in JJA to $-23 \%$ in SON, average of RCP 4.5 and 8.5) and Crete (from $-40 \%$ in JJA to $-5 \%$ in SON, average of RCP 4.5 and 8.5), while for Sicily and Crete an increase was observed $(+25 \%$, average of RCP 4.5 and 8.5$)$.

\section{Crop response to climate change}

Crops response to both future climate scenarios was firstly evaluated by aggregating, using averages, the results obtained for different sowing seasons and precocity levels adopted (Table 2).

This provided a general overview of the impact of climate change on crops, regardless of sowing time and precocity levels. The overall picture of the results indicated that there is a general advancement of the phenological stages for all crops, which is higher under RCP 8.5 than RCP 4.5, over the three sites as compared to the baseline. In Sicily, cereals and vegetables showed a yield increase compared to the baseline. The highest increase was found for potato $(+17 \%)$ and the lowest for tomato $(+3 \%)$. Both wheat and barley showed a general increase of $9 \%$. Amongst perennial crops, olive tree showed low variation under RCP 4.5 and an increase of $8 \%$ under RCP 8.5. By contrast, grapevine showed a production decrease under both scenarios, with the greatest losses under RCP 4.5 (-11\%). In Cyprus, wheat and barley showed a slight yield decrease under RCP $4.5(-2$ and $-1 \%$, respectively) and a slight increase under RCP 8.5 ( +4 and $+5 \%$, respectively). Vegetables showed an opposite pattern: whilst tomato showed a similar yield decrease for both RCPs ( $-6.5 \%$, on average), potato showed a considerable yield increase under both RCP $4.5(+17 \%)$ and RCP $8.5(+22 \%)$. Olive tree showed no variation under RCP 4.5 and a slight yield increase under RCP $8.5(+3 \%)$. Grapevine showed the greatest yield decrease among all crops, with a production reduction of 7 and $17 \%$ under RCP 4.5 and RCP 8.5 , respectively. In Crete, the general yield pattern reflected that observed for Cyprus. Wheat and barley showed a yield decrease under RCP 4.5 ( -7 and $-6 \%$, respectively) while it increased under RCP 8.5 ( +8 and $+9 \%$, respectively). Tomato showed a slight yield decrease for both RCPs $(-1.5 \%$, on average), whilst potato showed a considerable yield increase under both RCP $4.5(+11 \%)$ and RCP 8.5 $(+22 \%)$. Grapevine showed a strong yield decrease under RCP 4.5 (-9\%), whilst no changes were found under RCP 8.5 , compared to the baseline. Olive tree showed a slight yield increase under RCP $4.5(+2 \%)$ and a stronger increase under RCP $8.5(+10 \%)$, compared to the baseline.

\section{Crop response to sowing seasons, precocity levels and future climate scenarios}

\section{Wheat}

Under the baseline scenario, early autumn sowing provided the highest yield on all three islands (6326.3, 6017 and $5880 \mathrm{~kg} / \mathrm{ha}$ for Sicily, Cyprus and Crete, respectively) while a delayed sowing time from late autumn to spring resulted in a progressive yield decrease (Tables 3, 4, 5). This trend was associated to a progressive decrease in the AET:PET ratio (AET/PET) as sowing time moved from early autumn to spring (Tables $3,4,5)$. The phenological pattern of wheat on the three islands indicated that increased temperatures caused an earlier flowering and maturity time at any sowing date, as compared to the relevant baseline. In particular, the maximum advancement of phenological stages was observed in the warmer scenario (RCP 8.5) in a range of 1-3 weeks for both flowering and maturity depending on the sowing time, with the most evident advancements observed for earlier sowing times (early and late autumn). In the near future, the performances of wheat were generally better under RCP 8.5 than RCP 4.5 (Tables 3, 4, 5). In Sicily, early autumn sowing reached the best performances in both scenarios (+10 and $+12 \%$ in RCP 4.5 and 8.5, respectively), while this effect gradually decreased by shifting sowing times to the spring $(-0.9 \%$ and +3.9$)$. In Cyprus, the impact was 


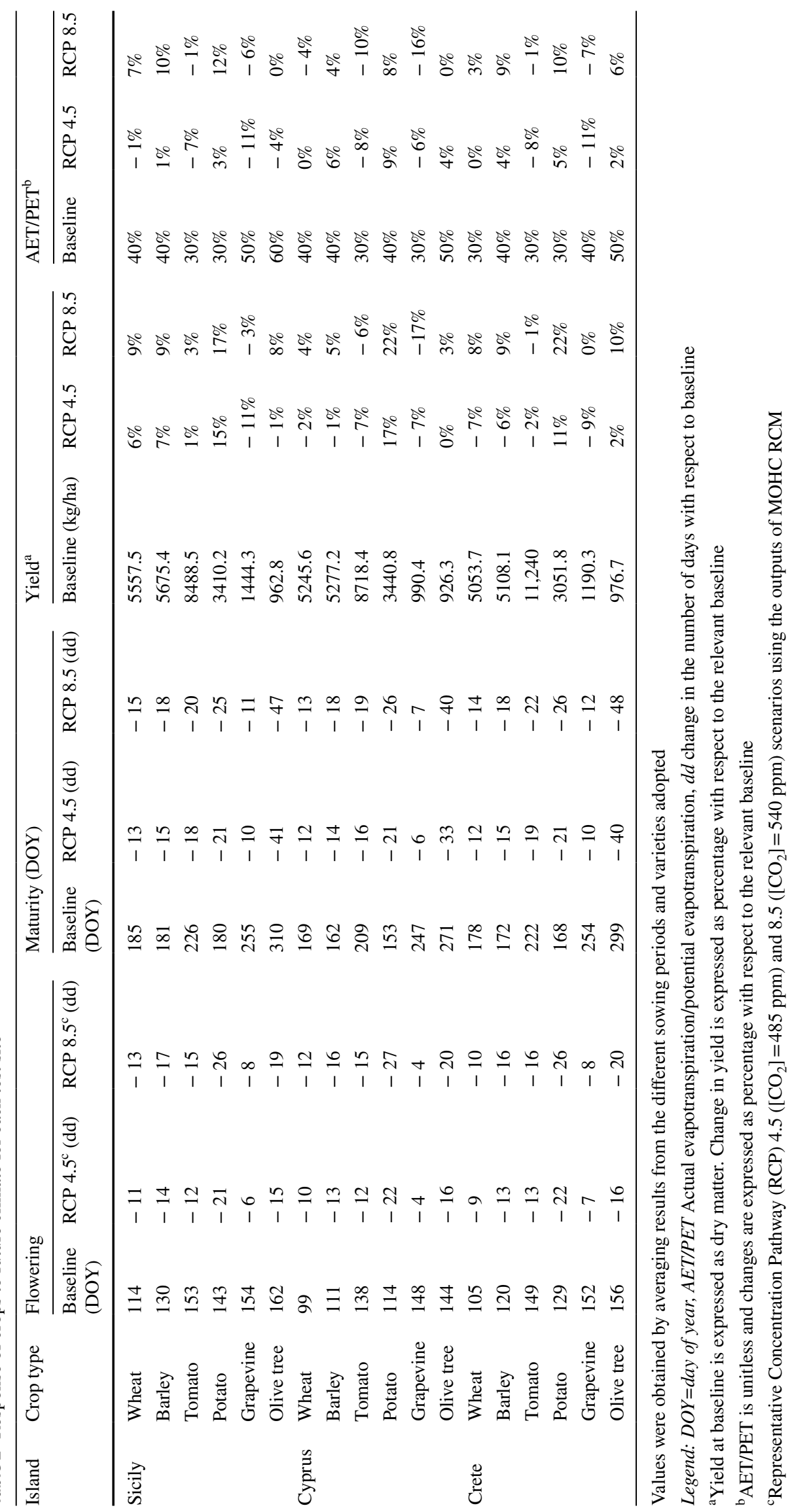




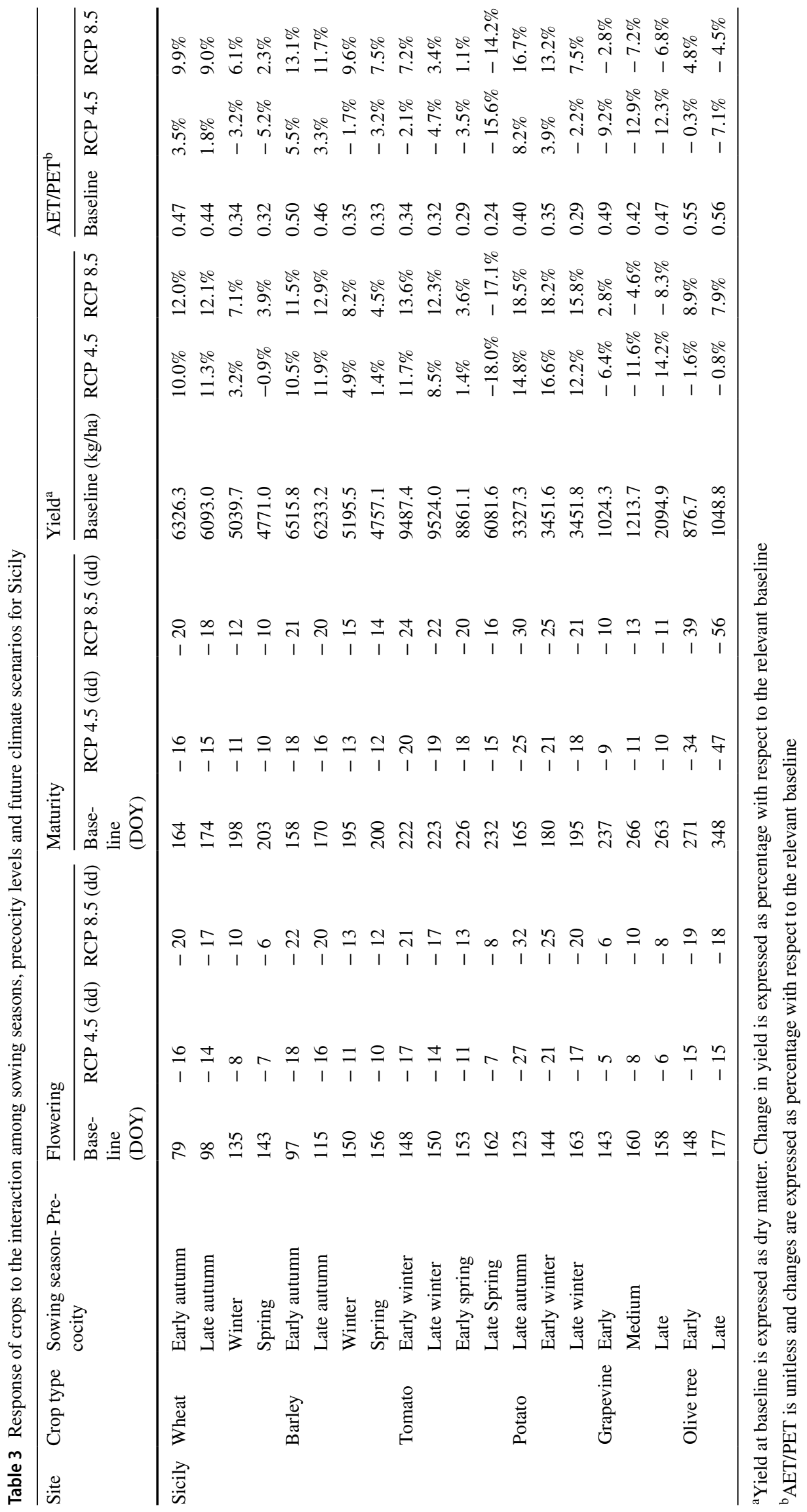




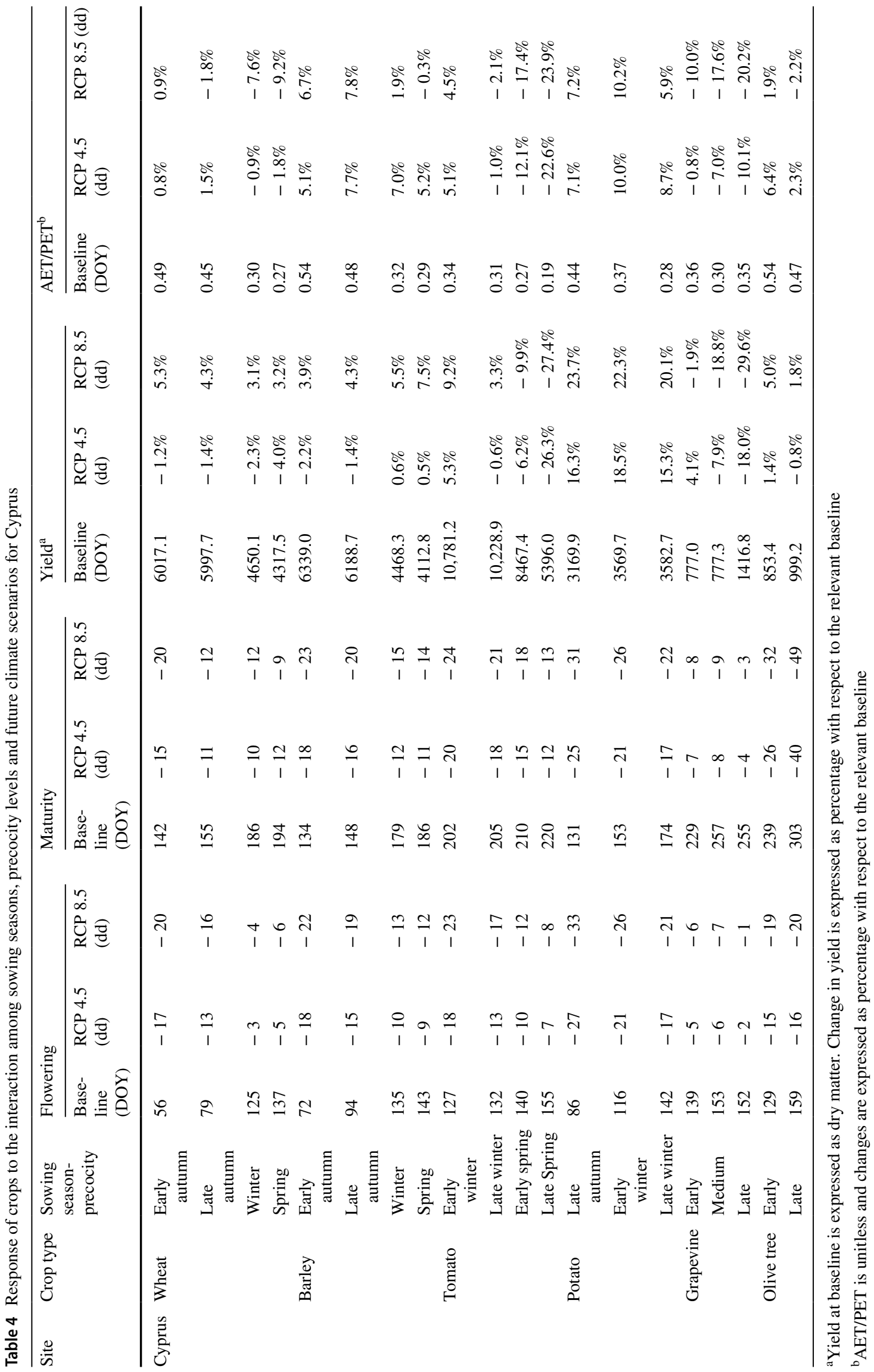




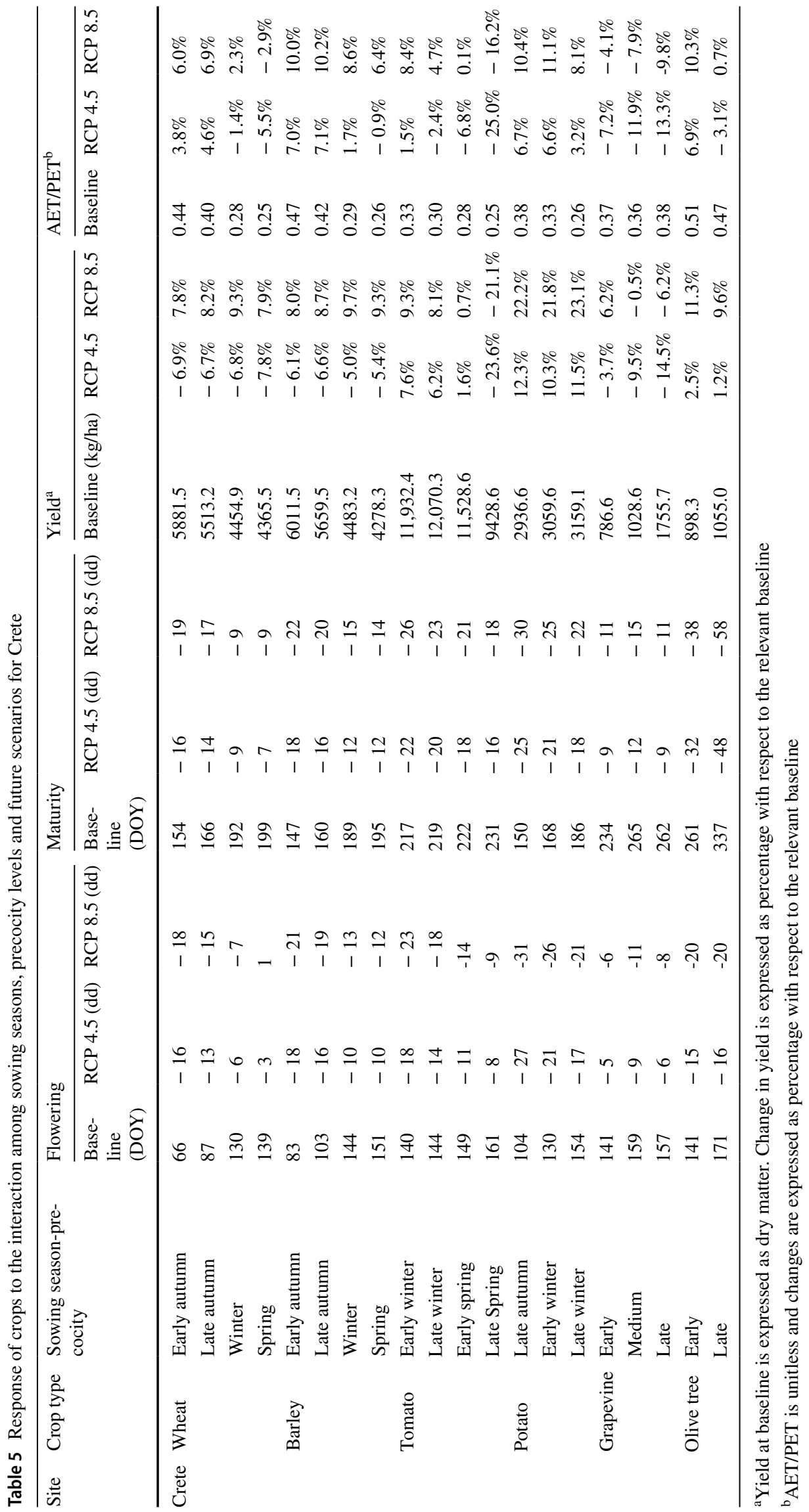


less positive, especially in RCP 4.5 where a general final yield reduction was observed, ranging from $-1.2 \%$ for early autumn to $-4 \%$ for spring. In RCP 8.5 , yield increased in early autumn sowing by $+5.3 \%$ with a decreasing trend up to spring (+3.2\%). Crete showed the same trend, with yield increases obtained under RCP 8.5, with the best performance for winter sowing $(+9.3 \%)$ and yield decreases in RCP 4.5 (worst performance in spring, $-7.8 \%$ ). In general, the AET/ PET tended to increase under both scenarios, especially for early/late autumn sowing time, where the highest increases were observed under RCP 8.5. Given these results, and taking into account that the best yield performances in the present period were obtained for early autumn sowing time, we may conclude that this time-window is still the best option for producing wheat in future periods on the three islands under both scenarios.

\section{Barley}

Under the baseline scenario, the highest yield was obtained using early autumn sowing $(6515.8,6339$ and $6011 \mathrm{~kg} / \mathrm{ha}$ in Sicily, Cyprus and Crete, respectively), which tended to decrease in response to a delayed sowing date, with a minimum for spring sowing (Tables 3, 4, 5). As observed for wheat, this trend is associated to a progressive increase in drought conditions, as indicated by a progressive decrease in AET/PET with respect to the early autumn sowing date (Tables 3, 4, 5). The results indicated that under future scenarios, flowering and maturity time occurred earlier, whatever the sowing date, with respect to the relevant baseline, with the highest advance in the RCP 8.5 scenario. Advancement of both flowering and maturity stage followed a similar pattern on the three islands where it progressively decreased as sowing time shifted from early autumn to spring. On average, flowering for early autumn sowing advanced by 18 and 22 days and flowering for spring sowing advanced up to 10 and 12 days in RCP 4.5 and 8.5, respectively (Tables 3, 4, 5). Under future scenarios, barley had similar performances as those described for wheat, where in general both RCPs had a positive effect on final yield, irrespective of sowing date. In Sicily, this effect was especially specific for sowing times in early autumn where barley yield increased by 10.5 and $11.5 \%$ in RCP 4.5 and 8.5 , progressively decreasing up to 1.4 and $4.5 \%$ for spring sowing, respectively. The impact in Cyprus was less positive, where in RCP 4.5 yield slightly decreased with early/late autumn sowing $(-2.2$ and $-1.4 \%)$ and slightly increased with winter and spring $(+0.6$ and $+0.5 \%$ ). Conversely, in RCP 8.5 , yield increase ranged from $+3.9 \%$ in early autumn sowing to $7.5 \%$ in the spring sowing. In Crete, the impact of the scenarios was different, where RCP 4.5 resulted in a general yield decrease, ranging from $-6.6 \%$ for late autumn sowing to $-5 \%$ for winter sowing, while RPC 8.5 yielded a general increase, ranging from $+9.7 \%$ for spring sowing to $+8 \%$ for early autumn sowing. In general, the AET/PET tended to increase under both scenarios especially for early/late autumn sowing, where the highest increases were observed under RCP8.5, from $10.2 \%$ for late autumn to $6.4 \%$ for spring. According to these results, and considering that the best yield performances in the present period were obtained for early autumn sowing on the three islands, we may conclude that this time-window is still the best option for producing barley in future periods according to both scenarios. In Sicily, early autumn sowing gained with respect to the baseline (10.5 and $11.5 \%$ in RCP 4.5 and 8.5), while in Cyprus and Crete, in the same timewindow the performances were slightly lower but in any case better than the other options.

\section{Tomato}

Under the baseline, early/late winter sowing provided the highest yield depending on the island $(9524 \mathrm{~kg} / \mathrm{ha}$ in late winter in Sicily, $10,781.2 \mathrm{~kg} / \mathrm{ha}$ in early winter in Cyprus and $12,070.3 \mathrm{~kg} / \mathrm{ha}$ in late winter in Crete) (Tables 3, 4, $5)$. When sowing was delayed to spring time, yield tended to decrease with respect to these maximum values, reaching its minimum with the late spring sowing $(-36.1,-50$ and $-21.9 \%$, respectively). This trend is associated to the AET/PET that progressively decreases when sowing time is delayed (from 0.33 to 0.25 ) (Tables 3, 4, 5). The phenological pattern indicated for each sowing time, an earlier occurrence of flowering and maturity under warmer scenarios compared to the baseline was more evident for early winter sowing time and in RCP 8.5, irrespective of sites. In general, as sowing time shifts to late spring, the advance of the phase becomes less pronounced (Tables 3, 4, 5). The effect of climate change was generally positive on tomato yield, especially on Crete and Sicily where for each sowing date yield increased in both scenarios, with a special relevance for early/late winter sowing that gained up to $13.6 \%$ in RCP 8.5 (Sicily). This positive trend decreased by shifting the sowing to late spring, where final yield was highly depressed with respect to the baseline by up to $-63.7 \%$ (Cyprus; RCP 4.5). AET/PET tended to increase with respect to the relevant baseline, especially for early winter sowing, while it was generally depressed as sowing shifted later to spring, especially in Crete where it decreased by -25 and $16 \%$ (RCP 4.5 and 8.5, respectively) with respect to the relevant baseline. In any case, considering yield of early/late winter sowing as a baseline to compare the performances of tomato in future scenarios, this time-window may still be considered as the optimal to cope with climate change. 


\section{Potato}

In the present period, highest yields on all three islands were generally reached when sowing in the winter season (early/late) where Cyprus showed the highest performance (3582 kg/ha), followed by Sicily (3451 kg/ha) and Crete (3159 kg/ha) (Tables 3, 4, 5). AET/PET generally showed higher values for late autumn sowing, which decreased when the sowing was delayed to late winter. In future scenarios, both anthesis and maturity advanced, with the highest effects being observed for late autumn sowing in RCP 8.5 on the three islands ( -30 days on average for anthesis and maturity) (Tables $3,4,5$ ). The impact on yield was generally positive, especially for late autumn sowing in RCP 8.5 that yielded an average increase of $21 \%$ (average over the three islands). This trend is associated to a generalised increase in AET/PET (Tables 3, 4, 5). According to these results, the most effective sowing date was later with respect to the baseline, from late autumn to early winter.

\section{Grapevine}

Under the baseline, the late variety provided the highest yield on all three islands $(2094.9,1416.8$ and $1755.7 \mathrm{~kg} / \mathrm{ha}$ for Sicily Cyprus and Crete, respectively), with yield gradually decreasing as the growing period shortened (Tables 3, $4,5)$. The AET/PET did not exhibit a particular trend but remained quite stable between early, medium and late varieties (0.45, 0.33 and 0.36, average for Sicily, Cyprus and Crete, respectively) (Tables 3, 4, 5). A warmer climate advanced anthesis and maturity stage, with slight differences between scenarios RCP 4.5 and 8.5, with an average advancement of 7 days for bud break and 9 days for maturity with respect to the baseline (average on all islands for RCP 8.5 and 4.5). Climate change had a general depressive impact on grape yield on the islands with a few exceptions for the early variety (Tables 3, 4, 5). The highest decreases were observed for varieties with a medium and late growing cycle, ranging from - $1.9 \%$ (early variety in RCP 8.5 ) to $-29.6 \%$ (late variety in RCP 8.5) in Cyprus. In general, this trend is associated to a progressive decrease in AET/ PET from the early to late variety. Despite early and medium varieties being shown to suffer less in a warmer climate, the late variety, even considering the large yield reduction in the future, still exhibited the best performances in terms of absolute yield.

\section{Olive tree}

Under the baseline period, the variety with the late growing cycle showed the best performances on all islands, with an average final yield of $1048 \mathrm{~kg} / \mathrm{ha}$ (average of Sicily, Cyprus and Crete), while the yield of the early variety was slightly lower (876 kg/ha) (Tables 3, 4, 5). ETA/ETP was generally higher for the early (0.53) compared to the late variety (0.5) (average of Sicily, Cyprus and Crete) (Tables 3, 4, 5). A warmer climate advanced both the anthesis and maturity stages with the effects more evident under RCP 8.5 than RCP4.5 (Tables 3, 4, 5). In general, a few differences were observed between varieties for anthesis, which was advanced on average by 15 days in RCP 4.5 and 19 days in RCP8.5 (average of Sicily, Cyprus and Crete). These differences increased at maturity, when differences between the early and late variety also became evident. As an example, under RCP 8.5 maturity of the early variety in Sicily was advanced by 39 days while that of the late variety advanced by 54 days, with respect to the baseline. Both scenarios had a generally good impact on final yield, especially for the early variety whose yield increased, with a few exceptions, up to $+11.3 \%$ (Crete, RCP 8.5); for the late variety, yield increases were more moderate (Tables $3,4,5)$. No clear pattern was observed for AET/PET. Despite the early variety showing a generally better response to climate change, the late variety still has the capacity to produce higher yield.

\section{Discussion}

In this paper, we focussed our attention on the agricultural systems of some of the most important islands of the Mediterranean, namely Sicily, Cyprus and Crete, to explore the possibility of adopting strategies to cope with climate change. Specifically, we propose to quantify the specific role of short-term autonomous adaptations to the agricultural supply of Sicily, Cyprus and Crete in response to climate change by coupling the outputs of an RCM to a suite of crop models specifically calibrated for the most important agricultural systems in the study areas. These models include the effect of extreme events on crop yield, as required for a reliable assessment of climate change by considering both mean climate and variability (Moriondo et al. 2015; Webber et al. 2018). Different sowing times for annual crops (wheat, barley, potato and tomato) and different growing season lengths of varieties of perennial crops (grapevine and olive tree) were tested to detect the most suitable adaptations to climate change, as outlined by the RCM MOHC downscaled to a spatial resolution of $12 \times 12 \mathrm{~km}$ over the islands. Our analysis consisted of two different steps: in the first step, the performances of each sowing date were separately evaluated in order to detect if a particular sowing time results in a yield reduction or increase in the face of climate change. This analysis identifies if, for a certain sowing time-window, the strategy improves the final yield (relative change). In the second step, after identifying for the baseline period the sowing time providing the highest yield for each crop, we used this 
value as a term of reference for selecting in every case the sowing time providing the highest yield (absolute change).

For annual crops, the results for the relative change indicated that winter crops, such as barley and wheat, had in most cases a low yield reduction or even a positive response to climate change, especially when sowing time is in the winter-autumn; this result is in line with those from other studies (Moriondo et al. 2010, 2013; Yang et al. 2019). However, the magnitude of these effects differs depending on the island and scenario, with the most positive effects being observed in Sicily and the most negative in Crete. These results rely on the fact that in Mediterranean regions, the phenological cycle of winter crops, such as wheat and barley, covers part of their growing season in autumn and winter, when rainfall is generally not limiting and even some increase in seasonal amount is projected (Fig. 3). Further, there is less crop exposure to the risk of extreme events, such as drought or heat-waves, that usually occur during summer and which are projected to increase (Shavrukov et al. 2017; Ruiz-Ramos et al. 2018), to which summer crops are conversely most exposed. This allows better yield performances, as indicated by our simulations on the three islands for the present period. As soon as sowing date shifts from early autumn to spring, the positive effect of climate change on yield is progressively reduced since the crop growing season is progressively moved towards warmer and drier weather conditions in the summer. For example, in Sicily the highest increase in barley and wheat yield is observed for early autumn sowing for both scenarios $(+10 \%$ on average), while it progressively decreases as sowing time moves to the spring ( $+2.5 \%$ on average). In particular, for wheat this strategy may be considered to be effective, as wheat requires no vernalisation to enter the growing phase. Yang et al. (2019) highlighted that in fact when vernalisation is required, an increase in temperature would imply a delay in chill unit accumulation and therefore a delay of anthesis, thereby reducing the possibilities of escaping the warmer period as would be expected from an earlier sowing. A different strategy may be adopted to reduce the risk of crop exposure to extreme events. While we used the same wheat and barley varieties as in the present period, Yang et al. (2019) indicated that the use of wheat varieties with early flowering and a rapid growth development relative to the reproductive phase reduces the exposure of crops to extreme events and results in a winning strategy for higher yields. Conversely, Asseng et al. (2019) pointed out that an extended vegetative growth may better compensate for the reduced growing season length induced by higher temperatures. In any case, this trait must be associated to a higher grain filling rate to escape the impact of the hot season.

The negative impact of drier and hotter conditions in summer is particularly evident for annual crops, such as tomato, or perennial crops, such as grapevine, whose growing cycle occurs in the spring-summer period. For tomato, while early sowing (early and late winter) had a generally positive effect on yield, as reported also by Garofalo and Rinaldi (2015), the opposite is observed when the sowing time is moved to late spring, where final yield was highly reduced with respect to the baseline (up to $-27.4 \%$ in Cyprus in RCP 8.5).

For grapevine, many studies have indicated that in most Mediterranean regions the combination of high temperatures and water deficits may have a detrimental impact on yield and quality (Iglesias et al. 2007; Moriondo et al. 2011; Fraga et al. 2012; Leolini et al., 2019), and the results presented in this paper are in line with those reported by these studies. Specifically, our results demonstrated that an early variety that is less subjected than a late one to drought and heat stress exhibited a reduced and even positive impact of climate change. Conversely, the shorter growing cycle reduces time for biomass accumulation and a crop yield that is much lower than that of a late variety, even though highly reduced with respect to the baseline.

For olive tree, there was a negligible effect of climate change on both the early and late variety which, in many cases, showed even positive performances with respect to the baseline. This finding reflects the results reported by Fraga et al. (2019) for southern Italy, including the Sardinia, Sicily and Apulia regions, who in a modelling study found that yield may change over a range of -8 to $+7 \%$. By contrast, Brilli et al. (2019) indicated only a progressive decrease in the productivity of olive groves exposed to warmer conditions, particularly when no irrigation is adopted. Our analysis of absolute changes (Electronic Supplementary Material Tables $\mathrm{S} 1$ and $\mathrm{S} 2$ ) pointed out that for annual crops advanced sowing time is the winning option for adapting in the short term, while for both olive tree and grapevine, late varieties are the best solutions for highest yield, even though our analysis of the results highlighted that late varieties suffered the impact of climate change the most.

When looking at the specific impact of future climate scenarios, it is evident from the results that RCP 8.5 had a generally positive effect on crop yields as compared to RCP 4.5 , which in many cases resulted in negative effects. Considering that RCP 8.5 is the worst climate scenario in terms of increasing temperatures and reduced rainfall, the results do not appear to be consistent. This apparent mismatch is due to the different concentrations of carbon dioxide concentrations used to drive crop growth simulations that played a major role in defining the different response between the two scenarios. In particular, the higher $\mathrm{CO}_{2}$ concentration for RCP 8.5 (560 ppm) compared with RCP 4.5 (460 ppm) enhanced the possibility of better crop performances due to enhanced photosynthetic activity (RUE) and better wather use efficiency (WUE). 
Some drawbacks of the framework used for this assessment must be highlighted. For the calibration of wheat and barley, we used yield data from experimental plots, and data from such experiments are usually higher than data obtained in actual growth conditions since in the former context, plants are not subjected to nitrogen stress or pests and diseases. This explains the high overestimation of final yield of both crops as simulated for the baseline period. Despite this drawback, however, the results obtained regarding the shifting sowing dates should be considered consistent as long as our aim is to explore the effect of future climate alone. In general, recent literature highlightsthat crop models' ensembles perform better than a single crop model in simulating the effect of climate on crop yield and phenology (Ehrhardt et al. 2018; Sándor et al. 2018). With respect to the future climate, the uncertainties in future simulations are usually addressed by considering the use of different RCMs as input of crop models. Conversely, in this work we used a single crop model for each crop and a single RCM as input; despite consistency with the weather conditions observed, the uncertainties related to each element cannot be evaluated.

\section{Practical implications}

The use of the results of this assessment can be considered the first step in an assessment of the impacts of climate change, which takes into account at a local level the peculiar characteristics of the production system. As an example of application, we report the Papadaskalopoulou et al. (2020) methodology that, according to the conceptual framework presented in the latest IPCC report, indicates that the total climate change impacts on agriculture is the result of a combination of climate change and the vulnerability of the exposed system and population. This was translated in the use of high spatial resolution information layers produced in this work, joined to socioeconomic information to outline the vulnerability profiles of the agricultural sector on a local scale in Cyprus. In particular, the study of the production performance of the most common crops in each region allows an assessment on an economic basis of which crops may represent a strength for local communities in the future to reduce system vulnerability.

\section{Conclusions}

The results of this study indicate that the expected impact of climate change and variability on three Mediterranean islands might be tackled using autonomous adaptation. This implies the use of an advanced sowing time for annual crops and the use of late varieties for perennial crops, such as grapevine and olive tree. Although this strategy will expose the plant more to the effects of climate change, it will still provide a higher yield efficiency. The results point out that although increasing temperature would reduce the time for biomass accumulation and a lower rainfall rate would enhance water stress, the proposed strategies may counterbalance these effects, also taking into account positive effect of higher $\mathrm{CO}_{2}$ concentrations on both photosynthesis and transpiration.

These results may be considered among the first that contribute to local adaptation on the Mediterranean islands, providing useful information for stakeholders and policymakers to cope with climate change by considering the specific vulnerability profiles of local communities and the expected changes of agricultural productivity. They thus provide an actual framework to test the effectiveness of local adaptation policies.

Supplementary Information The online version contains supplementary material available at https://doi.org/10.1007/s41207-021-00246-7.

Acknowledgement The work of PM was financially supported by the German Federal Ministry of Education and Research (BMBF) via the BARISTA project (031B0811A).

Funding Open access funding provided by Università degli Studi di Firenze.. This research was funded by the LIFE programme for the Environment and Climate Action (2014-2020) in the framework of the project LIFE ADAPT2CLIMA "Adaptation to Climate Change Impacts on the Mediterranean Islands' Agriculture" (LIFE14 CCA/ GR/000928).

\section{Compliance with ethical standards}

Conflict of interest The authors declare that they hat no conflict of interest. The funders had no role in the design of the study, in the collection, analyses, or interpretation of data, in the writing of the manuscript, or in the decision to publish the results.

Open Access This article is licensed under a Creative Commons Attribution 4.0 International License, which permits use, sharing, adaptation, distribution and reproduction in any medium or format, as long as you give appropriate credit to the original author(s) and the source, provide a link to the Creative Commons licence, and indicate if changes were made. The images or other third party material in this article are included in the article's Creative Commons licence, unless indicated otherwise in a credit line to the material. If material is not included in the article's Creative Commons licence and your intended use is not permitted by statutory regulation or exceeds the permitted use, you will need to obtain permission directly from the copyright holder. To view a copy of this licence, visit http://creativecommons.org/licenses/by/4.0/.

\section{References}

Asseng S, Foster I, Turner NC (2011) The impact of temperature variability on wheat yields. Glob Chang Biol 17:997-1012. https:// doi.org/10.1111/j.1365-2486.2010.02262.x

Asseng S, Ewert F, Martre P, Rötter RP, Lobell DB, Cammarano D, Kimball BA, Ottman MJ, Wall GW, White JW, Reynolds MP, 
Alderman PD, Prasad PVV, Aggarwal PK, Anothai J, Basso B, Biernath C, Challinor AJ, De Sanctis G, Doltra J, Fereres E, Garcia-Vila M, Gayler S, Hoogenboom G, Hunt LA, Izaurralde RC, Jabloun M, Jones CD, Kersebaum KC, Koehler AK, Müller C, Naresh Kumar S, Nendel C, O'Leary G, Olesen JE, Palosuo T, Priesack E, Eyshi Rezaei E, Ruane AC, Semenov MA, Shcherbak I, Stöckle C, Stratonovitch P, Streck T, Supit I, Tao F, Thorburn PJ, Waha K, Wang E, Wallach D, Wolf J, Zhao Z, Zhu Y (2015) Rising temperatures reduce global wheat production. Nat Clim Chang 5:143-147. https://doi.org/10.1038/nclimate2470

Asseng S, Martre P, Maiorano A, Rötter RP, O’Leary GJ, Fitzgerald GJ, Girousse C, Motzo R, Giunta F, Babar MA, Reynolds MP, Kheir AMS, Thorburn PJ, Waha K, Ruane AC, Aggarwal PK, Ahmed M, Balkovič J, Basso B, Biernath C, Bindi M, Cammarano D, Challinor AJ, De Sanctis G, Dumont B, Eyshi Rezaei E, Fereres E, Ferrise R, Garcia-Vila M, Gayler S, Gao Y, Horan H, Hoogenboom G, Izaurralde RC, Jabloun M, Jones CD, Kassie BT, Kersebaum KC, Klein C, Koehler AK, Liu B, Minoli S, Montesino San Martin M, Müller C, Naresh Kumar S, Nendel C, Olesen JE, Palosuo T, Porter JR, Priesack E, Ripoche D, Semenov MA, Stöckle C, Stratonovitch P, Streck T, Supit I, Tao F, Van der Velde M, Wallach D, Wang E, Webber H, Wolf J, Xiao L, Zhang Z, Zhao Z, Zhu Y, Ewert F (2019) Climate change impact and adaptation for wheat protein. Glob Chang Biol 25:155-173. https://doi.org/ 10.1111/gcb.14481

Brilli L, Moriondo M, Ferrise R, Dibari C, Bindi M (2014) Climate change and Mediterranean crops: 2003 and 2012, two possible examples of the near future. Agrochimica 58:1-14. https://doi. org/10.1400/226728

Brilli L, Lugato E, Moriondo M, Gioli B, Toscano P, Zaldei A, Leolini L, Cantini C, Caruso G, Gucci R, Merante P, Dibari C, Ferrise R, Bindi M, Costafreda-Aumedes S (2019) Carbon sequestration capacity and productivity responses of Mediterranean olive groves under future climates and management options. Mitig Adapt Strateg Glob Chang 24:467-491. https://doi.org/10.1007/ s11027-018-9824-x

Cammarano D, Ceccarelli S, Grando S, Romagosa I, Benbelkacem A, Akar T, Al-Yassin A, Pecchioni N, Francia E, Ronga D (2019) The impact of climate change on barley yield in the Mediterranean basin. Eur J Agron 106:1-11. https://doi.org/10.1016/j. eja.2019.03.002

Challinor AJ, Wheeler TR, Craufurd PQ, Slingo JM (2005) Simulation of the impact of high temperature stress on annual crop yields. Agric For Meteorol 135:180-189. https://doi.org/10.1016/j.agrfo rmet.2005.11.015

Challinor AJ, Watson J, Lobell DB, Howden SM, Smith DR, Chhetri $\mathrm{N}$ (2014) A meta-analysis of crop yield under climate change and adaptation. Nat Clim Chang 4:287-291. https://doi.org/10.1038/ nclimate 2153

Collins WJ, Bellouin N, Doutriaux-Boucher M, Gedney N, Halloran P, Hinton T, Hughes J, Jones CD, Joshi M, Liddicoat S, Martin G, O'Connor F, Rae J, Senior C, Sitch S, Totterdell I, Wiltshire A, Woodward S (2011) Development and evaluation of an EarthSystem model-HadGEM2. Geosci Model Dev 4:1051-1075. https://doi.org/10.5194/gmd-4-1051-2011

Cramer W, Guiot J, Fader M, Garrabou J, Gattuso JP, Iglesias A, Lange MA, Lionello P, Llasat MC, Paz S, Peñuelas J, Snoussi M, Toreti A, Tsimplis MN, Xoplaki E (2018) Climate change and interconnected risks to sustainable development in the Mediterranean. Nat Clim Chang 8:972-980. https://doi.org/10.1038/ s41558-018-0299-2

Ehrhardt F, Soussana JF, Bellocchi G, Grace P, McAuliffe R, Recous S, Sándor R, Smith P, Snow V, de Antoni MM, Basso B, Bhatia A, Brilli L, Doltra J, Dorich CD, Doro L, Fitton N, Giacomini SJ, Grant B, Harrison MT, Jones SK, Kirschbaum MUF, Klumpp K, Laville P, Léonard J, Liebig M, Lieffering M, Martin R, Massad
RS, Meier E, Merbold L, Moore AD, Myrgiotis V, Newton P, Pattey E, Rolinski S, Sharp J, Smith WN, Wu L, Zhang Q (2018) Assessing uncertainties in crop and pasture ensemble model simulations of productivity and $\mathrm{N} 2 \mathrm{O}$ emissions. Glob Chang Biol 24:e603-e616. https://doi.org/10.1111/gcb.13965

European Environment Agency (2018) National climate change vulnerability and risk assessments in Europe. EEA Report No 01/2018. European Environment Agency, Copenhagen. https:// www.eea.europa.eu/publications/national-climate-change-vulne rability-2018

Ewert F, Rötter RP, Bindi M, Webber H, Trnka M, Kersebaum KC, Olesen JE, van Ittersum MK, Janssen S, Rivington M, Semenov MA, Wallach D, Porter JR, Stewart D, Verhagen J, Gaiser T, Palosuo T, Tao F, Nendel C, Roggero PP, Bartošová L, Asseng S (2015) Crop modelling for integrated assessment of risk to food production from climate change. Environ Model Softw 72:287303. https://doi.org/10.1016/j.envsoft.2014.12.003

Fraga H, Malheiro AC, Moutinho-Pereira J, Santos JA (2012) An overview of climate change impacts on European viticulture. Food Energy Secur 1:94-110. https://doi.org/10.1002/fes3.14

Fraga H, Pinto JG, Santos JA (2019) Climate change projections for chilling and heat forcing conditions in European vineyards and olive orchards: a multi-model assessment. Clim Change 152:179193. https://doi.org/10.1007/s10584-018-2337-5

Garofalo P, Rinaldi M (2015) Impact of climate change and adaptation strategies on irrigationand tomato productivity: a long-term case study in Mediterranean environment. Acta Hortic 1081:89-96. https://doi.org/10.17660/ActaHortic.2015.1081.8

Georgopoulou E, Mirasgedis S, Sarafidis Y, Vitaliotou M, Lalas DP, Theloudis I, Giannoulaki KD, Dimopoulos D, Zavras V (2017) Climate change impacts and adaptation options for the Greek agriculture in 2021-2050: a monetary assessment. Clim Risk Manag 16:164-182. https://doi.org/10.1016/j.crm.2017.02.002

Giorgi F, Lionello P (2008) Climate change projections for the Mediterranean region. Glob Planet Chang 63:90-104. https://doi.org/ 10.1016/j.gloplacha.2007.09.005

Haylock MR, Hofstra N, Klein Tank AMG, Klok EJ, Jones PD, New M (2008) A European daily high-resolution gridded data set of surface temperature and precipitation for 1950-2006. J Geophys Res Atmos 113:D20.https://doi.org/10.1029/2008JD010201

Herrmann M, Somot S, Calmanti S, Dubois C, Sevault F (2011) Representation of spatial and temporal variability of daily wind speed and of intense wind events over the Mediterranean Sea using dynamical downscaling: impact of the regional climate model configuration. Nat Hazards Earth Syst Sci 11:1983-2001. https:// doi.org/10.5194/nhess-11-1983-2011

Howden SM, Soussana JF, Tubiello FN, Chhetri N, Dunlop M, Meinke $\mathrm{H}$ (2007) Adapting agriculture to climate change. Proc Natl Acad Sci USA 104:19691-19696. https://doi.org/10.1073/pnas.07018 90104

Iglesias A, Avis K, Benzie M, Fisher P, Harley M, Hodgson N, Horrocks L, Moneo M, Webb J (2007) Adaptation to climate change in the agricultural sector. Report to European Commission Directorate-General for Agriculture and Rural Development. Report AGRI-2006-G4-05.AEA Energy \& Environment and Universidad de Politécnica, Madrid

Kovats RS, Valentini R, Bouwer LM, Georgopoulou E, Jacob D, Martin E, Rounsevell M, Soussana JF (2015) European climate change 2014 impacts, adaptation, vulnerability. In: Barros VR, Field CB, Dokken DJ, et al. (eds) DClimate change 2014: impacts, adaptation, and vulnerability. Part B: regional aspects. Cambridge University, Press, Cambridge, pp 1267-1326. https://doi.org/10.1017/ CBO9781107415386.003

Leolini L, Bregaglio S, Moriondo M, Ramos MC, Bindi M, Ginaldi F (2018) A model library to simulate grapevine growth and development: software implementation, sensitivity analysis and field level 
application. Eur J Agron 99:92-105. https://doi.org/10.1016/j.eja. 2018.06.006

Leolini L, Moriondo M, Romboli Y, Gardiman M, Costafreda-Aumedes S, Costafreda-Aumedes S, Bindi M, Granchi L, Brilli L (2019) Modelling sugar and acid content in Sangiovese grapes under future climates: an Italian case study. Clim Res 78:211-224. https://doi.org/10.3354/cr01571

Lionello P, Scarascia L (2018) The relation between climate change in the Mediterranean region and global warming. Reg Environ Chang 18:1481-1493. https://doi.org/10.1007/s10113-018-1290-1

Martin GM, Bellouin N, Collins WJ, Culverwell ID, Halloran PR, Hardiman SC, Hinton TJ, Jones CD, McDonald RE, McLaren AJ, O'Connor FM, Roberts MJ, Rodriguez JM, Woodward S, Best MJ, Brooks ME, Brown AR, Butchart N, Dearden C, Derbyshire SH, Dharssi I, Doutriaux-Boucher M, Edwards JM, Falloon PD, Gedney N, Gray LJ, Hewitt HT, Hobson M, Huddleston MR, Hughes J, Ineson S, Ingram WJ, James PM, Johns TC, Johnson CE, Jones A, Jones CP, Joshi MM, Keen AB, Liddicoat S, Lock AP, Maidens AV, Manners JC, Milton SF, Rae JGL, Ridley JK, Sellar A, Senior CA, Totterdell IJ, Verhoef A, Vidale PL, Wiltshire A (2011) The HadGEM2 family of Met Office Unified Model climate configurations. Geosci Model Dev 4:723-757. https://doi.org/10.5194/ gmd-4-723-2011

Moriondo M, Bindi M, Kundzewicz ZW, Szwed M, Chorynski A, Matczak P, Radziejewski M, McEvoy D, Wreford A (2010) Impact and adaptation opportunities for European agriculture in response to climatic change and variability. Mitig Adapt Strateg Glob Chang 15:657-679. https://doi.org/10.1007/s11027-010-9219-0

Moriondo M, Bindi M, Fagarazzi C, Ferrise R, Trombi G (2011) Framework for high-resolution climate change impact assessment on grapevines at a regional scale. Reg Environ Chang 11:553-567. https://doi.org/10.1007/s10113-010-0171-Z

Moriondo M, Jones GV, Bois B, Dibari C, Ferrise R, Trombi G, Bindi M (2013) Projected shifts of wine regions in response to climate change. Clim Chang 119:825-839. https://doi.org/10.1007/ s10584-013-0739-y

Moriondo M, Argenti G, Ferrise R, Dibari C, Trombi G, Bindi M (2015) Heat stress and crop yields in the Mediterranean basin: impact on expected insurance payouts. Reg Environ Chang 16:1877-1890. https://doi.org/10.1007/s10113-015-0837-7

Moriondo M, Leolini L, Brilli L, Dibari C, Tognetti R, Giovannelli A, Rapi B, Battista P, Caruso G, Gucci R, Argenti G, Raschi A, Centritto M, Cantini C, Bindi M (2019) A simple model simulating development and growth of an olive grove. Eur J Agron 105:129-145. https://doi.org/10.1016/j.eja.2019.02.002

Papadaskalopoulou C, Moriondo M, Lemesios I, Karali A, Konsta A, Dibari C, Brilli L, Varotsos KV, Stylianou A, Loizidou M, Markou M, Giannakopoulos C (2020) Assessment of total climate change impacts on the agricultural sector of Cyprus. Atmosphere (Basel) 11:608. https://doi.org/10.3390/atmos11060608

Popke D, Stevens B, Voigt A (2013) Climate and climate change in a radiative-convective equilibrium version of ECHAM6. J Adv Model Earth Syst 5:1-14. https://doi.org/10.1029/2012MS000191

Ruiz-Ramos M, Ferrise R, Rodríguez A, Lorite IJ, Bindi M, Carter TR, Fronzek S, Palosuo T, Pirttioja N, Baranowski P, Buis S,
Cammarano D, Chen Y, Dumont B, Ewert F, Gaiser T, Hlavinka P, Hoffmann H, Höhn JG, Jurecka F, Kersebaum KC, Krzyszczak J, Lana M, Mechiche-Alami A, Minet J, Montesino M, Nendel C, Porter JR, Ruget F, Semenov MA, Steinmetz Z, Stratonovitch P, Supit I, Tao F, Trnka M, de Wit A, Rötter RP (2018) Adaptation response surfaces for managing wheat under perturbed climate and CO2 in a Mediterranean environment. Agric Syst 159:260274. https://doi.org/10.1016/j.agsy.2017.01.009

Sándor R, Ehrhardt F, Brilli L, Carozzi M, Recous S, Smith P, Snow V, Soussana JF, Dorich CD, Fuchs K, Fitton N, Gongadze K, Klumpp K, Liebig M, Martin R, Merbold L, Newton PCD, Rees RM, Rolinski S, Bellocchi G (2018) The use of biogeochemical models to evaluate mitigation of greenhouse gas emissions from managed grasslands. Sci Total Environ 642:292-306. https://doi. org/10.1016/j.scitotenv.2018.06.020

Shavrukov Y, Kurishbayev A, Jatayev S, Shvidchenko V, Zotova L, Koekemoer F, De Groot S, Soole K, Langridge P (2017) Early flowering as a drought escape mechanism in plants: how can it aid wheat production? Front Plant Sci 8:1-8. https://doi.org/10. 3389/fpls.2017.01950

Stöckle CO, Donatelli M, Nelson R (2003) CropSyst, a cropping systems simulation model. Eur J Agron 18:289-307. https://doi.org/ 10.1016/S1161-0301(02)00109-0

Strandberg G, Bärring L, Hansson U, Jansson C, Jones C, Kjellström E, Kolax M, Marco Kupiainen G, Nikulin PS, Wang AU (2014) CORDEX scenarios for Europe from the Rossby Centre regional climate model RCA4. Rep Meteorol Clim 116:1-84

Taylor KE (2001) Summarizing multiple aspects of model performance in a single diagram. J Geophys Res Atmos 106:7183-7192. https://doi.org/10.1029/2000JD900719

Vicente-Serrano SM, Lopez-Moreno JI, Beguería S, Lorenzo-Lacruz J, Sanchez-Lorenzo A, García-Ruiz JM, Azorin-Molina C, MoránTejeda E, Revuelto J, Trigo R, Coelho F, Espejo F (2014) Evidence of increasing drought severity caused by temperature rise in southern Europe. Environ Res Lett. https://doi.org/10.1088/ 1748-9326/9/4/044001

Voldoire A, Sanchez-Gomez E, Salas y Mélia D, Decharme B, Cassou C, Sénési S, Valcke S, Beau I, Alias A, Chevallier M, Déqué M, Deshayes J, Douville H, Fernandez E, Madec G, Maisonnave E, Moine MP, Planton S, Saint-Martin D, Szopa S, Tyteca S, Alkama R, Belamari S, Braun A, Coquart L, Chauvin F (2013) The CNRM-CM5.1 global climate model: description and basic evaluation. Clim Dyn 40:2091-2121. https://doi.org/10.1007/ s00382-011-1259-y

Webber $\mathrm{H}$ et al (2018) Diverging importance of drought stress for maize and winter wheat in Europe. Nat Commun 9(1):1-10

Yang C, Fraga H, van Ieperen W, Trindade H, Santos JA (2019) Effects of climate change and adaptation options on winter wheat yield under rainfed Mediterranean conditions in southern Portugal. Clim Change 154:159-178. https://doi.org/10.1007/ s10584-019-02419-4 